\title{
Sprawozdanie z wyjazdu do Archiwum Instytutu im. gen. Sikorskiego w Londynie w 2016 r.
}

W trakcie zeszłorocznego wyjazdu do Londynu (10 tygodni, 1 sierpnia - 23 września i 12-23 grudnia 2016 r.) kontynuowane było porządkowanie materiałów archiwalnych. Zajmowałem się wyłącznie aktami zidentyfikowanymi jako rozkazy.

Dział „Rozkazów” to wydzielona część zasobu. Składają się na nią wyłącznie rozkazy pisemne regulujące codzienny tok służby poszczególnych jednostek czy placówek Polskich Sił Zbrojnych. Rozkazy dla konkretnych oddziałów czy pododdziałów to kolejne wydzielone jednostki (mogą się jeszcze dzielić na kolejne lata). Oznaczane są literą „R” i kolejną liczbą arabską. Do rozpoczęcia zeszłorocznych prac Instytut posiadał 1572 jednostki rozkazów. Około 400 jest zeskanowanych, ale udostępnionych poprzez stronę internetową jest na razie tylko kilkadziesiąt ${ }^{1}$.

Akta do porządkowania pozyskiwane były z akt przekazanych przez Brytyjczyków, nieuporządkowanych jeszcze i niewłączonych do zasobu. Początek pracy to wyselekcjonowanie grupy akt zidentyfikowanych jako rozkazy. Następnie konieczne było sprawdzenie, czy odnalezione dokumenty już znajdują się w zasobie. Jeżeli takie już były, pozbawiano je elementów metalowych, układano, pakowano w obwolutę i spisywano jako dublet. Jeżeli nie stwierdzono, że rozkazy danej jednostki są w zasobie, należało przygotować je do włączenia do zasobu. Pierwszą czynnością było, jak zawsze, pozbawianie wszelkich elementów metalowych, następnie układano w kolejności (według numerów rozkazów) poszczególne dokumenty. Formowano jednostki, przyjmując najczęściej, że jeden rok to osobna jednostka dla poszczególnych oddziałów i placówek. Finalnie opisywano obwoluty, wpisywano do ewidencji i pakowano w pudła. Zdarzały się też sytuacje, że z porządkowanych akt należało włączyć tylko część, dotychczas brakującą. W takich przypadkach dodawano brakujące numery (czy nawet pojedyncze rozkazy) do jednostki i oczywiście korygowano ewidencję. Jeżeli takie uzupełnienie przypadło na już zeskanowaną jednostkę - to w takim przypadku formowana była całkowicie nowa, a stosowne adnotacje umieszczano przy opisach obydwu jednostek.

Łącznie w trakcie opisywanego wyjazdu udało się opracować i włączyć 194 j.a. (liczące 4,2 mb) - sygn. R.1573 do R.1766. Oprócz akt włączonych do zasobu, kolejne 4 mb wyłączone zostały też jako dublety. Akta zachowały się na ogół w dobrym stanie, jedynie dwie jednostki były zagrzybione i zostały odseparowane.

Wśród włączonych jednostek były zarówno większe grupy rozkazów, np. sporo zostało odnalezionych rozkazów oddziałów Brygady Spadochronowej, Centrum Wyszkolenia Artylerii czy nieznane do teraz rozkazy jednostki o nazwie Oficerski Kurs Doskonalący

${ }^{1}$ Strona Instytutu Polskiego i Muzeum im. gen. Sikorskiego http://www.pism.co.uk/dokumenty_ r1.htm (odczyt: 27.01.2017). 
Administracji Wojskowej (czyli zakamuflowanej szkoły „Cichociemnych” dowodzonej przez płk. Stefana Meyera). Włączenie do obiegu tych akt można uznać za ważne osiągnięcie w pracach archiwalnych w Instytucie. Zdarzały się też rozkazy mniej znanych jednostek czy placówek - jak np. Garnizonowa Kasa Chorych St. Didier czy Ośrodek Szkolenia Zawodowego Rybaków Morskich. Porządkując akta powojenne, powstałe w czasie funkcjonowania Polskiego Korpusu Przysposobienia i Rozmieszczenia (PKPR), zauważyć można było zmiany, jakim podlegały oddziały wojskowe przekształcane w jednostki PKPR-u. Był to proces demobilizacji wojska i przygotowywania ludzi do osiedlenia się i rozpoczęcia pracy w jakimś wyuczonym zawodzie.

Wśród materiałów, jakie pozostały, z pewnością znajdują się jeszcze rozkazy, poza tym inne, związane choćby z jednostkami I Korpusu Polskiego w Wielkiej Brytanii.

Mariusz Kluczewski Archiwum Narodowe w Krakowie 